\title{
Juncus emmanuelis
}

\section{Assessment by: García Murillo, P.G., Carapeto, A., Pinto Cruz, C., Ríos Ruiz, S. \& Fraga i Arquimbau, P.}

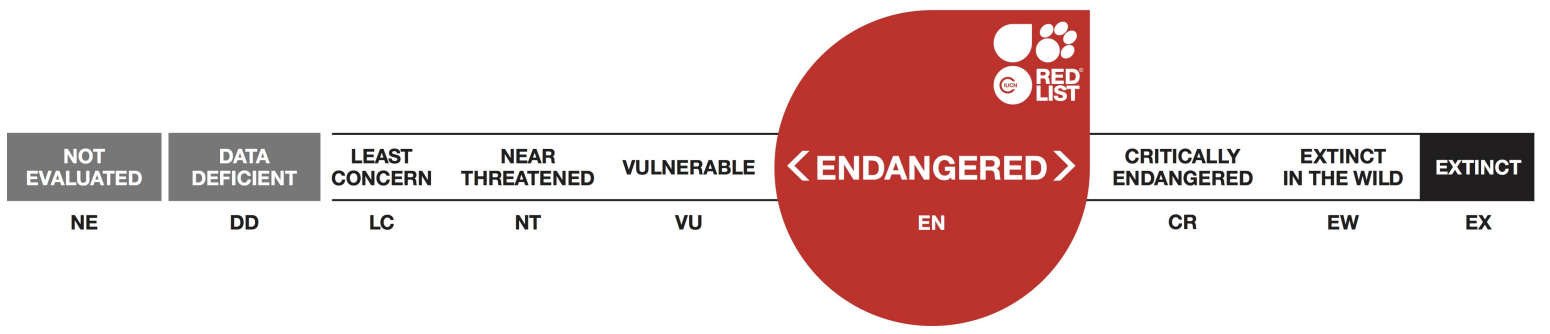

View on www.iucnredlist.org

Citation: García Murillo, P.G., Carapeto, A., Pinto Cruz, C., Ríos Ruiz, S. \& Fraga i Arquimbau, P. 2018. Juncus emmanuelis. The IUCN Red List of Threatened Species 2018: e.T13164423A18614355. http://dx.doi.org/10.2305/IUCN.UK.2018-1.RLTS.T13164423A18614355.en

Copyright: (C 2018 International Union for Conservation of Nature and Natural Resources Reproduction of this publication for educational or other non-commercial purposes is authorized without prior written permission from the copyright holder provided the source is fully acknowledged.

Reproduction of this publication for resale, reposting or other commercial purposes is prohibited without prior written permission from the copyright holder. For further details see Terms of Use.

The IUCN Red List of Threatened Species ${ }^{T M}$ is produced and managed by the IUCN Global Species Programme, the IUCN Species Survival Commission (SSC) and The IUCN Red List Partnership. The IUCN Red List Partners are: Arizona State University; BirdLife International; Botanic Gardens Conservation International; Conservation International; NatureServe; Royal Botanic Gardens, Kew; Sapienza University of Rome; Texas A\&M University; and Zoological Society of London.

If you see any errors or have any questions or suggestions on what is shown in this document, please provide us with feedback so that we can correct or extend the information provided. 


\section{Taxonomy}

\begin{tabular}{|c|c|c|c|c|}
\hline Kingdom & Phylum & Class & Order & Family \\
\hline Plantae & Tracheophyta & Liliopsida & Poales & Juncaceae \\
\hline
\end{tabular}

Taxon Name: Juncus emmanuelis A.Fern. \& J.G.García

\section{Synonym(s):}

- Juncus emmanuelis A.Fern. \& J.G.García var. inflatifolius A.Fern. \& J.G.García

\section{Taxonomic Source(s):}

Fernandez-Carvajal, M.C. 1982. Revision del genero Juncus L. en la peninsula iberica. IV. subgeneros Juncinella (Fourr.) Krecz. \& Gontsch., Septati Buchenau y Alpini Buchenau. Anales Jardin Botanico de Madrid 39 (2): 301-379.

\section{Assessment Information}

Red List Category \& Criteria: Endangered B2ab(ii,iii,iv) ver 3.1

Year Published: 2018

Date Assessed:

December 16, 2015

\section{Justification:}

This species is endemic to a small area in the southwestern Iberian Peninsula, with subpopulations scattered in approximately 16 localities. It is assessed as Endangered (EN B2ab(ii,iii,iv)) because it has an Area of Occupancy (AOO) of less than $500 \mathrm{~km}^{2}$ and shows signs of severe fragmentation due to the ongoing transformation of its specific habitat of sandy soils with an impermeable underlayer in temporary pools, as a result of several ongoing major threats associated with intensive agricultural activities. Based on this information, a continuing decline in the AOO, habitat quality and number of subpopulations has been inferred. Additional research and conservation action is needed for this species.

\section{Geographic Range}

\section{Range Description:}

This rush is endemic to the southwest of the Iberian Peninsula, where it has only been recorded from very localized sites in the southern half of Portugal (Alto Alentejo, Baixo Alentejo, Estremadura, Algarve and Ribatejo provinces) and southwestern Spain (Huelva Province), in western Andalusia (Fernandez Carvajal 1977, Romero-Zarco 2010, Sociedade Portuguesa de Botânica 2012-2014, Anthos 2015).

\section{Country Occurrence:}

Native: Portugal (Portugal (mainland)); Spain (Spain (mainland)) 


\section{Distribution Map}

Juncus emmanuelis

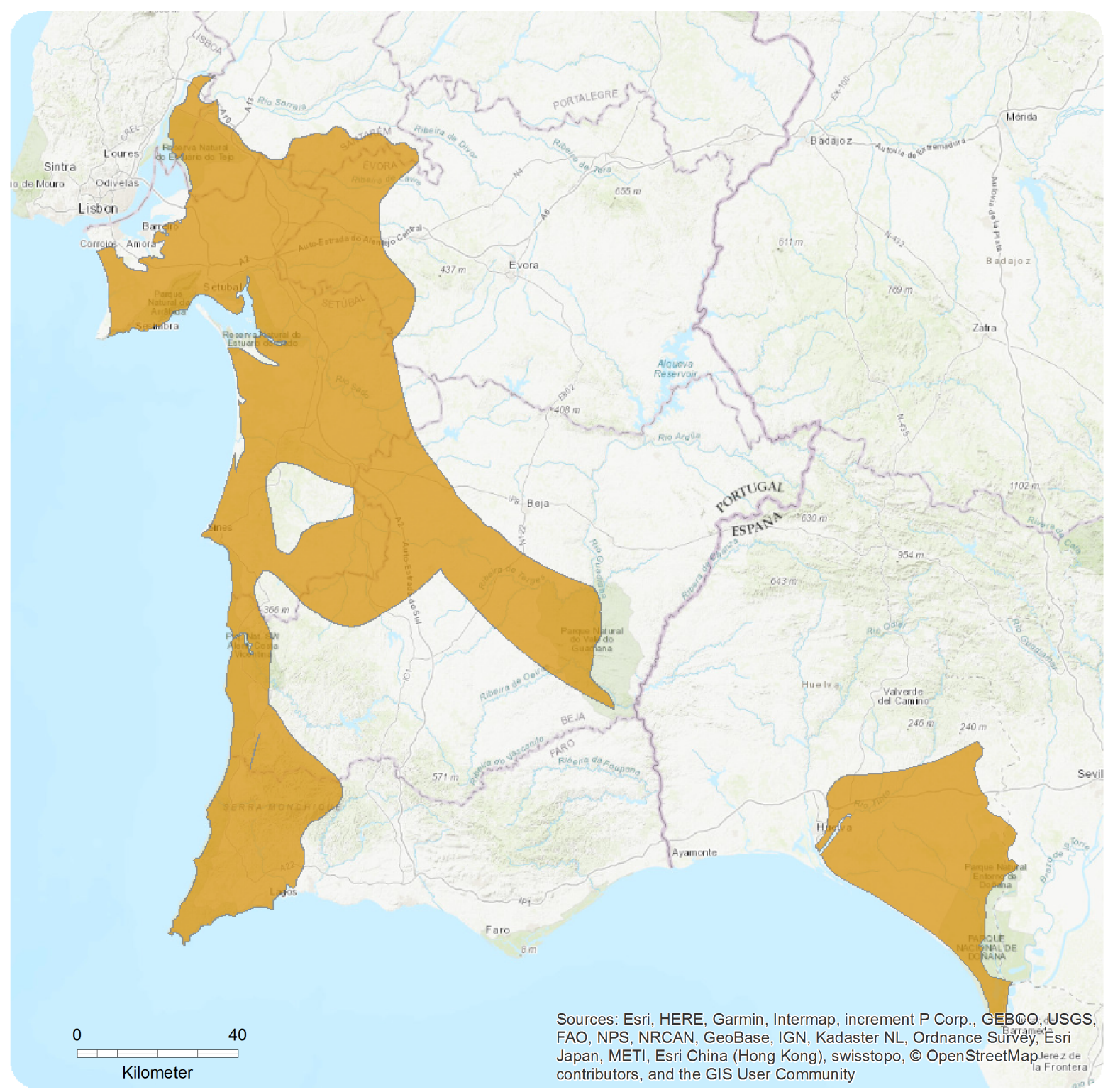

Range

Extant (resident)
Compiled by:

IUCN Mediterranean Red List

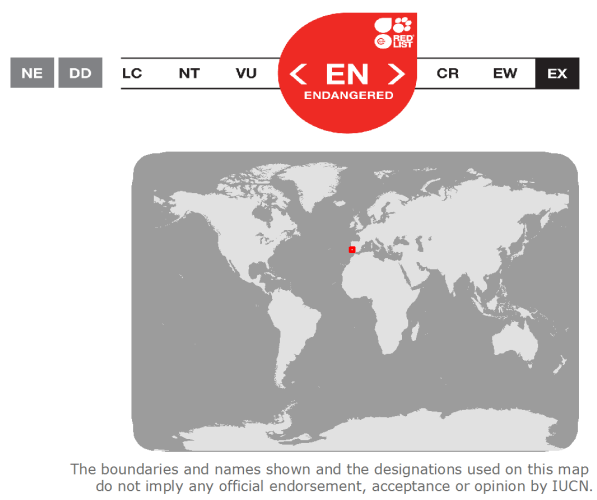




\section{Population}

This rush has a small AOO with severely fragmented and isolated subpopulations distributed in approximately 16 localities. In Portugal, despite occurring in small areas, populations are sometimes dense. In general, most subpopulations of this species are significantly disconnected with very little to no exchange and suspected to have reached no viable level because of their ecological dependence on habitats with very poor sandy wet soils, which are currently in decline due to changes in the nature of the soil and water as a result of the increasing use of fertilizers in intensive agricultural practices and other ongoing human activities such as livestock overgrazing and tourist development.

Current Population Trend: Decreasing

\section{Habitat and Ecology (see Appendix for additional information)}

This plant inhabits temporary pools, where it is mostly found on sandy soils with an impermeable underlayer, a habitat poor in nutrients and with little mineralization.

Systems: Terrestrial, Freshwater

\section{Use and Trade}

This taxon is not utilized.

\section{Threats (see Appendix for additional information)}

The main threats to this species are habitat degradation and destruction, particularly due to the development of new intensive agricultural practices since 1980s such as the use of fertilizers, pesticides, agricultural effluents, sedimentation and infrastructures, which affect greatly the habitat of this species. Other important threats to the species are livestock ranching and overgrazing and the development of touristic infrastructures within its distributional range. Also in a global context, the increased effect of droughts due to processes associated to climate change is expected to represent a significant threat in the future.

\section{Conservation Actions (see Appendix for additional information)}

This species occurs in several protected areas (IUCN and UNEP-WCMC 2017). Most of the population of this species occurs in habitat designated as priority under the European Habitats Directive (EEC European Economic Community 1992).

In Spain, this species is protected at regional level under the designation of "taxa of special interest" by Decreto 33/1998, de 5 de mayo de1998, in Comunidad de Castilla-La Mancha. It is also included in the Regional Red List of the Andalusia region as DD by (Cabezudo et al. 2005).

Studies oriented to survey the potential occurrence of this species also in North Africa are suggested, since the same kind of habitat is also present. Research studies for evaluating trends and threats to its 
population, as well as the ecological requirements of this species are also advised. Other recommended conservation actions include legislation development at national and sub-national level, habitat protection, site management and ex-situ conservation.

\section{Credits}

Assessor(s): $\quad$ García Murillo, P.G., Carapeto, A., Pinto Cruz, C., Ríos Ruiz, S. \& Fraga i Arquimbau, P.

Reviewer(s): $\quad$ García, N. \& Allen, D.J.

Contributor(s): $\quad$ Rodriguez Merino, A., Fernandez Zamudio, R. \& Alcázar Montañez, E.

Facilitators(s) and Barrios, V.

Compiler(s): 


\section{Bibliography}

Anthos. 2015. Sistema de información sobre las plantas de España. Madrid; Real Jardín Botánico, CSIC Fundación Biodiversidad Available at: http://www.anthos.es.

Cabezudo, B., Talavera, S., Blanca, G., Salazar, C., Cueto, M., Valdés, B., Hernandez Bermejo, J.E., Herrera, C.M., Rodriguez Hiraldo, C. and Navas, D. 2005. Lista Roja de la Flora Vascular de Andalucía. Consejeria de Medio Ambiente, Junta de Andalucía, Sevilla.

EEC. 1992. The Habitats Directive - Council Directive 92/43/EEC of 21 May 1992. European Economic Community. Official Journal of the European Communities.

Fernandez Carvajal, MC. 1977. Juncus emmanuelis Fernandes \& Garcia en la Peninsula Iberica. Anales Instituto Botanico Cavanilles 34(1): 125-131.

IUCN. 2018. The IUCN Red List of Threatened Species. Version 2018-1. Available at: www.iucnredlist.org. (Accessed: 28 June 2018).

IUCN and UNEP-WCMC. 2017. The World Database on Protected Areas (WDPA).

www.protectedplanet.net. Cambridge, UK Available at: $\underline{w w w . p r o t e c t e d p l a n e t . n e t . ~}$

Romero-Zarco, C. 2010. Juncus L. In: Talavera, S., Gallego, M.J., Romero Zarco, C. and Herrero, A. (eds), Flora Iberica, pp. 123-187. Consejo Superior de Investigaciones Científicas, Madrid.

Sociedade Portuguesa de Botânica. 2012-2014. Flora-On. Available at: http://www.floraon.pt/index.php\#. (Accessed: July 2015).

\section{Citation}

García Murillo, P.G., Carapeto, A., Pinto Cruz, C., Ríos Ruiz, S. \& Fraga i Arquimbau, P. 2018. Juncus emmanuelis. The IUCN Red List of Threatened Species 2018: e.T13164423A18614355.

http://dx.doi.org/10.2305/IUCN.UK.2018-1.RLTS.T13164423A18614355.en

\section{Disclaimer}

To make use of this information, please check the Terms of Use.

\section{External Resources}

For Images and External Links to Additional Information, please see the Red List website. 


\section{Appendix}

\section{Habitats}

(http://www.iucnredlist.org/technical-documents/classification-schemes)

\begin{tabular}{|c|c|c|c|}
\hline Habitat & Season & Suitability & $\begin{array}{l}\text { Major } \\
\text { Importance? }\end{array}$ \\
\hline $\begin{array}{l}\text { 5. Wetlands (inland) -> 5.8. Wetlands (inland) - Seasonal/Intermittent } \\
\text { Freshwater Marshes/Pools (under 8ha) }\end{array}$ & Resident & Suitable & Yes \\
\hline
\end{tabular}

\section{Threats}

\section{(http://www.iucnredlist.org/technical-documents/classification-schemes)}

\begin{tabular}{|c|c|c|c|c|}
\hline Threat & Timing & Scope & Severity & Impact Score \\
\hline \multirow{9}{*}{$\begin{array}{l}\text { 11. Climate change \& severe weather -> 11.2. } \\
\text { Droughts }\end{array}$} & Future & Unknown & Unknown & Unknown \\
\hline & Stresses: & \multirow{6}{*}{\multicolumn{3}{|c|}{$\begin{array}{l}\text { 1. Ecosystem stresses }->1.1 \text {. Ecosystem conversion } \\
\text { 1. Ecosystem stresses }->1.2 \text {. Ecosystem degradation } \\
\text { 1. Ecosystem stresses }->1.3 \text {. Indirect ecosystem effects } \\
\text { 2. Species Stresses }->2.1 \text {. Species mortality } \\
\text { 2. Species Stresses }->\text { 2.2. Species disturbance } \\
\text { 2. Species Stresses }->\text { 2.3. Indirect species effects }-> \\
\text { 2.3.2. Competition }\end{array}$}} \\
\hline & & & & \\
\hline & & & & \\
\hline & & & & \\
\hline & & & & \\
\hline & & & & \\
\hline & & \multicolumn{3}{|c|}{$\begin{array}{l}\text { 2. Species Stresses }->2.3 \text {. Indirect species effects }-> \\
\text { 2.3.7. Reduced reproductive success }\end{array}$} \\
\hline & & \multicolumn{3}{|c|}{$\begin{array}{l}\text { 2. Species Stresses }->2.3 \text {. Indirect species effects -> } \\
\text { 2.3.8. Other }\end{array}$} \\
\hline \multirow{7}{*}{$\begin{array}{l}\text { 2. Agriculture \& aquaculture }->2.1 \text {. Annual \& } \\
\text { perennial non-timber crops }->2.1 .4 \text {. Scale } \\
\text { Unknown/Unrecorded }\end{array}$} & Ongoing & $\begin{array}{l}\text { Majority (50- } \\
90 \%)\end{array}$ & Rapid declines & $\begin{array}{l}\text { Medium } \\
\text { impact: } 7\end{array}$ \\
\hline & Stresses: & \multirow{6}{*}{\multicolumn{3}{|c|}{$\begin{array}{l}\text { 1. Ecosystem stresses }->1.1 \text {. Ecosystem conversion } \\
\text { 1. Ecosystem stresses }->1.2 \text {. Ecosystem degradation } \\
\text { 2. Species Stresses }->2.1 \text {. Species mortality } \\
\text { 2. Species Stresses }->2.2 \text {. Species disturbance } \\
\text { 2. Species Stresses }->\text { 2.3. Indirect species effects }-> \\
\text { 2.3.2. Competition } \\
\text { 2. Species Stresses }->\text { 2.3. Indirect species effects }-> \\
\text { 2.3.8. Other }\end{array}$}} \\
\hline & & & & \\
\hline & & & & \\
\hline & & & & \\
\hline & & & & \\
\hline & & & & \\
\hline \multirow{7}{*}{$\begin{array}{l}\text { 2. Agriculture \& aquaculture }->2.3 \text {. Livestock farming } \\
\text { \& ranching }->2.3 .1 \text {. Nomadic grazing }\end{array}$} & Ongoing & Unknown & Unknown & Unknown \\
\hline & Stresses: & \multicolumn{3}{|c|}{ 1. Ecosystem stresses $->1.2$. Ecosystem degradation } \\
\hline & & \multirow{3}{*}{\multicolumn{3}{|c|}{$\begin{array}{l}\text { 1. Ecosystem stresses }->1.3 \text {. Indirect ecosystem effects } \\
\text { 2. Species Stresses }->2.2 \text {. Species disturbance } \\
\text { 2. Species Stresses }->2.3 \text {. Indirect species effects }-> \\
\text { 2.3.2. Competition }\end{array}$}} \\
\hline & & & & \\
\hline & & & & \\
\hline & & \multicolumn{3}{|c|}{$\begin{array}{l}\text { 2. Species Stresses }->2.3 \text {. Indirect species effects -> } \\
\text { 2.3.7. Reduced reproductive success }\end{array}$} \\
\hline & & \multicolumn{3}{|c|}{$\begin{array}{l}\text { 2. Species Stresses }->2.3 \text {. Indirect species effects -> } \\
\text { 2.3.8. Other }\end{array}$} \\
\hline $\begin{array}{l}\text { 2. Agriculture \& aquaculture }->2.3 \text {. Livestock farming } \\
\& \text { ranching }->2.3 .2 \text {. Small-holder grazing, ranching or } \\
\text { farming }\end{array}$ & Ongoing & $\begin{array}{l}\text { Majority (50- } \\
90 \%)\end{array}$ & $\begin{array}{l}\text { Slow, significant } \\
\text { declines }\end{array}$ & $\begin{array}{l}\text { Medium } \\
\text { impact: } 6\end{array}$ \\
\hline
\end{tabular}




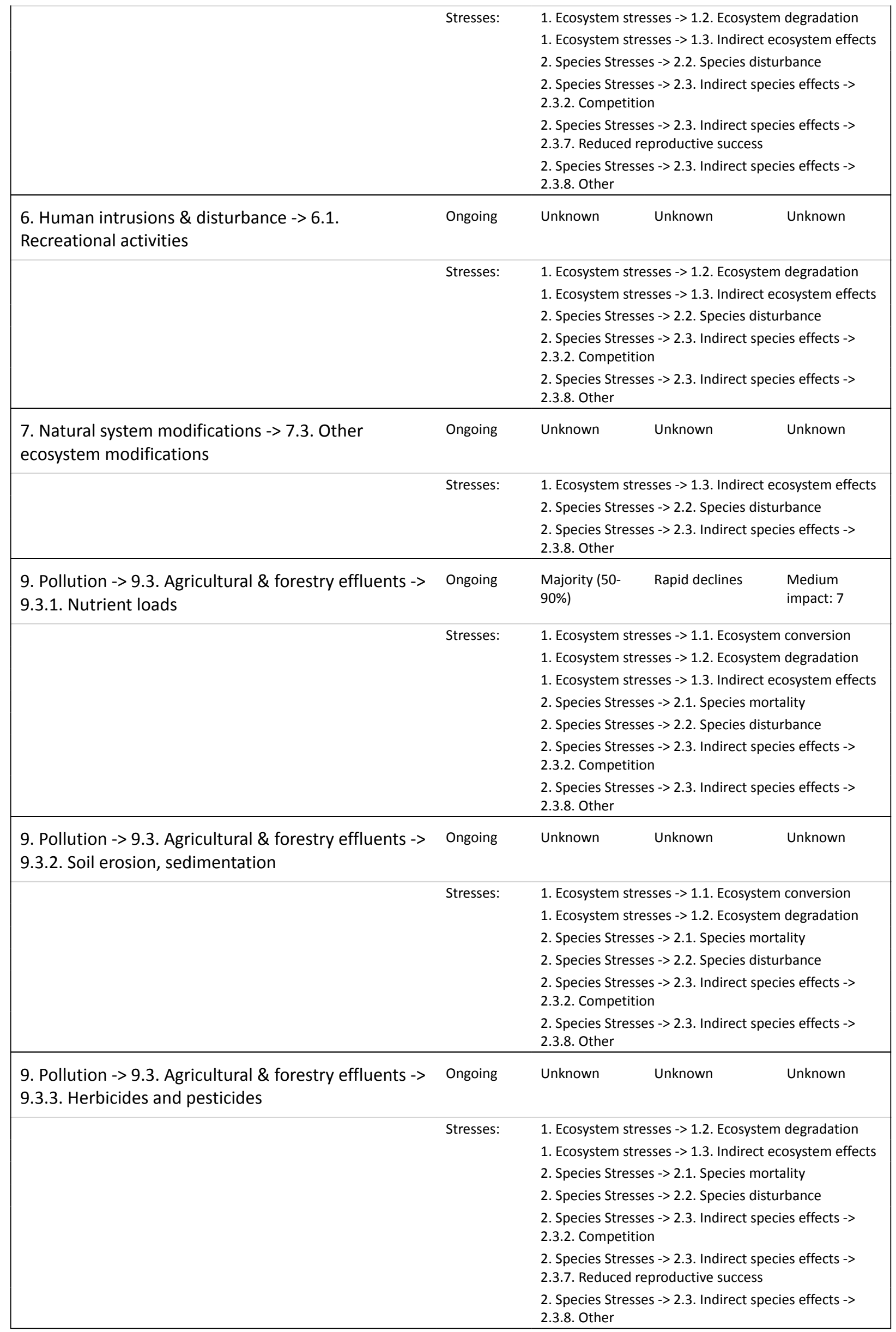




$\begin{array}{ll}\text { Ongoing } & \text { Unknown Unknown Unknown } \\ \text { Stresses: } & \text { 1. Ecosystem stresses }->\text { 1.2. Ecosystem degradation } \\ & \text { 1. Ecosystem stresses }->1.3 \text {. Indirect ecosystem effects } \\ & \text { 2. Species Stresses }->\text { 2.2. Species disturbance } \\ & \text { 2. Species Stresses }->\text { 2.3. Indirect species effects }-> \\ & \text { 2.3.2. Competition } \\ & \text { 2. Species Stresses }->\text { 2.3. Indirect species effects }-> \\ \text { 2.3.8. Other }\end{array}$

\section{Conservation Actions in Place}

(http://www.iucnredlist.org/technical-documents/classification-schemes)

\section{Conservation Actions in Place}

In-Place Land/Water Protection and Management

Occur in at least one PA: Yes

\section{Conservation Actions Needed}

(http://www.iucnredlist.org/technical-documents/classification-schemes)

\section{Conservation Actions Needed}

1. Land/water protection $->1.2$. Resource \& habitat protection

2. Land/water management -> 2.1. Site/area management

3. Species management -> 3.4. Ex-situ conservation -> 3.4.2. Genome resource bank

5. Law \& policy -> 5.1. Legislation -> 5.1.2. National level

5. Law \& policy -> 5.1. Legislation -> 5.1.3. Sub-national level

\section{Research Needed}

(http://www.iucnredlist.org/technical-documents/classification-schemes)

\begin{tabular}{|l|}
\hline Research Needed \\
\hline 1. Research $->$ 1.2. Population size, distribution \& trends \\
\hline 1. Research $->$ 1.3. Life history \& ecology \\
\hline 1. Research $->$ 1.5. Threats \\
\hline 3. Monitoring $->$ 3.1. Population trends \\
\hline 3. Monitoring $->$ 3.4. Habitat trends \\
\hline
\end{tabular}

\section{Additional Data Fields}




\section{Distribution}

Estimated area of occupancy (AOO) $\left(\mathrm{km}^{2}\right): 284$

Continuing decline in area of occupancy (AOO): Yes

Extreme fluctuations in area of occupancy (AOO): Unknown

Estimated extent of occurrence (EOO) $\left(\mathrm{km}^{2}\right): 55951$

Continuing decline in extent of occurrence (EOO): Unknown

Continuing decline in number of locations: Yes

Extreme fluctuations in the number of locations: Unknown

Lower elevation limit $(m): 0$

Upper elevation limit (m): 200

Population

Continuing decline of mature individuals: Unknown

Extreme fluctuations: No

Population severely fragmented: Yes

Habitats and Ecology

Continuing decline in area, extent and/or quality of habitat: Yes 


\section{The IUCN Red List Partnership}

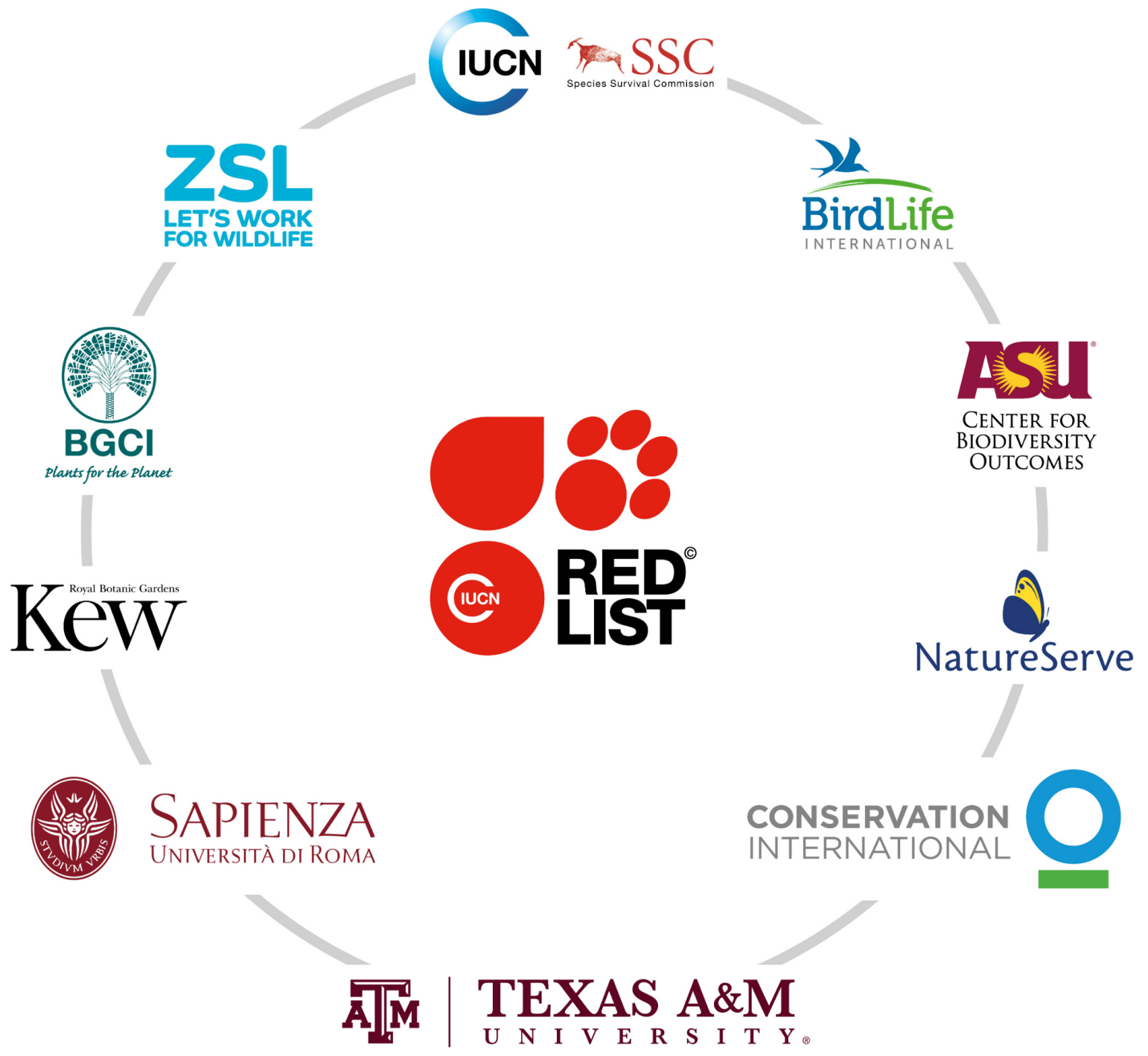

The IUCN Red List of Threatened Species ${ }^{\mathrm{TM}}$ is produced and managed by the IUCN Global Species Programme, the IUCN Species Survival Commission (SSC) and The IUCN Red List Partnership.

The IUCN Red List Partners are: Arizona State University; BirdLife International; Botanic Gardens Conservation International; Conservation International; NatureServe; Royal Botanic Gardens, Kew; Sapienza University of Rome; Texas A\&M University; and Zoological Society of London. 